\title{
Comparison of different fixation methods of bicolumnar acetabular fractures
}

\author{
Çift kolonlu asetabulum kırıklarının farklı tespit yöntemlerinin karşılaştırıması
}

\author{
Tamás Bodzay, MD, PhD, ${ }^{1}$ Gergely Sztrinkai, MD, ${ }^{1}$ András Kocsis, MD, ${ }^{1}$ Báliinstnt Kozma, ${ }^{3}$ \\ Tamás Gál, MD, ${ }^{2}$ Károly Váradi, PhD, D.Sc. ${ }^{3}$ \\ ${ }^{1}$ Trauma Centre, Péterfy Hospital, Budapest, Hungary \\ ${ }^{2}$ Department of Trauma, Semmelweis University, Budapest, Hungary \\ ${ }^{3}$ Faculty of Mechanical Engineering, Institute of Machine Design, Budapest, Hungary
}

\begin{abstract}
Objectives: This study aims to investigate if the stabilization of iliac wing fractures influences the stability of the acetabular osteosynthesis, if surgical fixation is the choice of treatment, and which technique to be used.
\end{abstract}

Materials and methods: In the study, measurements were performed with an improved finite element model. Tension and displacement values were measured in bicolumnar acetabular fractures in the following cases: combination of cranial and medial plate fixation through the linea terminalis, or combination of cranial plate and quadrilateral surface plates. The iliac wing fracture was either not fixed, or fixed with screws or with a plate.

Results: In cases where osteosynthesis was performed through the linea terminalis, $0.01 \mathrm{~mm}$ fracture gap displacement was observed with the use of a combination of cranial and quadrilateral surface plate fixations. In the combination of cranial and medial positioned plates, the displacement in the fracture gap was $0.088 \mathrm{~mm}$. The fixation of the iliac wing fracture did not improve the stability of the osteosynthesis of the linea terminalis. Plate fixation of the iliac wing fracture was more stable than screw fixation alone.

Conclusion: In double column fractures, if the reduction does not require an anterior approach, it is not necessary to fix the iliac wing fracture only to improve the stability of the fixation. If the reduction does require an anterior approach, it is worth fixing the iliac wing fracture with the technically less demanding screw fixation.

Keywords: Acetabular fracture; cranial plate; iliac wing fracture; medial plate; quadrilateral surface plate.
ÖZ

Amaç: $\mathrm{Bu}$ çalışmada iliyak kanat kırıklarının stabilizasyonunun asetabüler osteosentezin stabilitesini etkileyip etkilemediği, cerrahi tespitin tercih edilen tedavi olup olmadığ 1 ve kullanılacak tekniğin hangisi olduğu araştırıldı.

Gereç ve yöntemler: Çalışmada ölçümler iyileştirilmiş bir sonlu eleman modeli ile yapıldı. Çift kolonlu asetabulum kırıklarında gerginlik ve displasman değerleri aşağıdaki olgularda ölçüldü: Linea terminalis boyunca kraniyal ve medial plak tespiti kombinasyonu veya kraniyal plak ve dörtgen yüzeyli plak kombinasyonu. İliyak kanat kırığ ya tespit edilmedi ya da vidalarla veya bir plak ile tespit edildi.

Bulgular: Osteosentezin linea terminalis boyunca yapıldığ olgularda kraniyal ve dörtgen yüzeyli plak tespitlerinin kombinasyonunun kullanılması ile 0.01 mm'lik kırık boşluğu displasmanı gözlemlendi. Kraniyal ve medial konumlu plakların kombinasyonunda kırık boşluğundaki displasman $0.088 \mathrm{~mm}$ idi. İliyak kanat kırığının tespiti linea terminalisin osteosentezinin stabilitesini iyileştirmedi. İliyak kanat kırığının plak tespiti sadece vida tespitinden daha stabil idi.

Sonuç: Çift kolonlu kırıklarda eğer redüksiyon anterior yaklaşım gerektirmiyorsa iliyak kanat kırığını sadece tespitin stabilitesini iyileştirmek için tespit etmek gerekli değildir. Eğer redüksiyon anterior yaklaşım gerektiriyorsa iliyak kanat kırığını teknik olarak daha az zorlayıcı olan vida tespiti ile tespit etmeye değerdir.

Anahtar sözcükler: Asetabulum kırığı; kraniyal plak; iliyak kanat kırı̆̆ı; medial plak; dörtgen yüzeyli plak.

- Received: December 22, 2017 Accepted: January 27, 2018

- Correspondence: Tamás Bodzay, MD, PhD. Trauma Centre, Péterfy Hospital Fiumei str. 17. H-1081, Budapest, Hungary. Tel: +36203178188 e-mail: bodzaytamas@freemail.hu 
Isolated iliac wing fractures usually do not influence the stability of the pelvic ring and typically do not require osteosynthesis; therefore, nonoperative treatment is generally the choice of therapy. Exceptions include open fractures, widely displaced fractures, long-lasting persistent pain (3-4 weeks), or increasing secondary displacement. ${ }^{[1]}$ The case is different if the iliac wing fracture is an associated injury of an acetabulum fracture or if the fracture line crosses the linea terminalis influencing the stability of the pelvis ring. In fractures of the anterior column or in bicolumnar fractures, we often see the fracture line "running" to and through the iliac wing. If we chose to use the Judet-Letournel approach to operate on these fractures, the iliac wing can usually be exposed through an anterior window. If a Stoppa or pararectus approach is used for the intrapelvic surgery, ${ }^{[2,3]}$ the exposure to the anterior window is performed only in cases when the acetabulum fracture requires reduction, i.e. reducing the displaced iliac wing fracture aids us in the reduction of the acetabulum.

In these cases, we have a possibility of fixing the iliac wing component. For the fixation of the iliac wing fracture, two different techniques exist: plate or screw fixation..$^{[1]}$

Concerning the osteosynthesis of the bicolumnar fracture, a question arises regarding which fixation provides greater stability of the fracture: the combination of cranial and medial plate to the linea terminalis, or the combination of cranial and quadrilateral surface plates? The second question is whether to additionally perform fixation of the iliac wing or not, and which technique should we use?

To answer these questions, it helps to know whether the surgical fixation of the iliac wing will influence the stability of the osteosynthesis of the acetabulum fracture. ${ }^{[4]}$ Therefore, in this study, we aimed to investigate if the stabilization of iliac wing fractures influences the stability of the acetabular osteosynthesis, if surgical fixation is the choice of treatment, and which technique to be used.

\section{MATERIALS AND METHODS}

The numeric simulation was performed in 2016, in the Institute of Machine Design, Faculty of Mechanical Engineering, University of Technology and Economics, Budapest. The study was conducted in accordance with the principles of the Declaration of Helsinki.

Anatomic model: we used the previous, realisticgeometry pelvis model from our earlier experiments for this study. ${ }^{[5]}$ We simulated a bicolumnar acetabulum fracture with one of the following fixation methods: combination of cranial and medial plate fixation through the linea terminalis, or combination of cranial and quadrilateral surface plates. The fracture running through the iliac wing was either not fixed, fixed with screws only, or fixed with a plate.

Geometric model: In the realistic geometric model, we modeled node-to node contact in the hip joint and at the fracture site, whereas a bonded contact was modeled in all other intact joints (symphysis and sacroiliac joints).

Material model: we used a linear elastic material model; the material properties can be seen in Table I. ${ }^{[5]}$ The used material properties are the elastic modulus and the Poisson's ratio. These material properties are dedicated for the description of the deformity of elastic, rigid bodies under pressure. We removed the cancellous bone elements of so-called hollow bone model, since our previous experiments have demonstrated that the cancellous bone layer does not significantly partake in the loading; therefore, it can be neglected without causing misinterpretation of the results. ${ }^{[6]}$ For this reason, we only modelled the cortical layer, thus the table only contains those material properties. It can be seen that the elastic modulus of the ligaments is about five times greater than that of the joints, thus demonstrating their

TABLE I

Material properties in model

\begin{tabular}{lccc}
\hline & $\begin{array}{c}\text { Elastic modulus } \\
(\mathrm{MPa})\end{array}$ & $\begin{array}{c}\text { Poisson ratio } \\
(-)\end{array}$ & $\begin{array}{c}\text { Rated maximal tension } \\
(\mathrm{MPa})\end{array}$ \\
\hline Corticalis & 17000 & 0.3 & 70 \\
Ligament & 355 & 0.2 & - \\
Symphysis & 50 & 0.2 & - \\
Sacroiliac joint & 68 & 0.2 & - \\
American Iron and Steel Institute 316L & 200000 & 0.265 & 500 \\
Contact material & 100 & 0.4 & - \\
\hline
\end{tabular}


importance in their attachment to the bone; hence, the disregard of this is unacceptable. Among the joints, the symphysis is less stiff. Although the degree of this is not too significant, we nonetheless took it into consideration since it did not affect the measuring time, yet gave more accurate results. We simulated a catalogue indexed American Iron and Steel Institute 316L stainless steel type implant in our experiments. The validation of the model was performed on cadaver experiments, as mentioned in our previous publication, ${ }^{[7]}$ that is, we modeled Denis type I sacrum fracture and symphysiolysis; the symphysiolysis was fixed with a four-hole plate and the sacrum fracture was fixed with either a transsacral plate or direct plate synthesis.

\section{Load and rim parameters}

Case 1- Bicolumnar acetabular fracture, weight bearing on both lower extremities: load on the promontorium, in the Z-axis, $500 \mathrm{~N}$, both femurs fixed, the pelvis is posteriorly supported against displacement in the Y-axis; node-to node contact in both hip joints and at the fracture site; bonded contact in other joints; neighboring the acetabulumcranial and medial plate fixations through the linea terminalis; no fixation of the iliac wing fracture.

Case 2- Bicolumnar acetabular fracture, weight bearing on both lower extremities: load on the promontorium, in the Z-axis, $500 \mathrm{~N}$, both femurs fixed, the pelvis is posteriorly supported against displacement in the Y-axis; node-to node contact in both hip joints and at the fracture site; bonded contact in other joints; neighboring the acetabulum-cranial plate and quadrilateral surface plate fixation through the linea terminalis; no fixation of the iliac wing fracture.

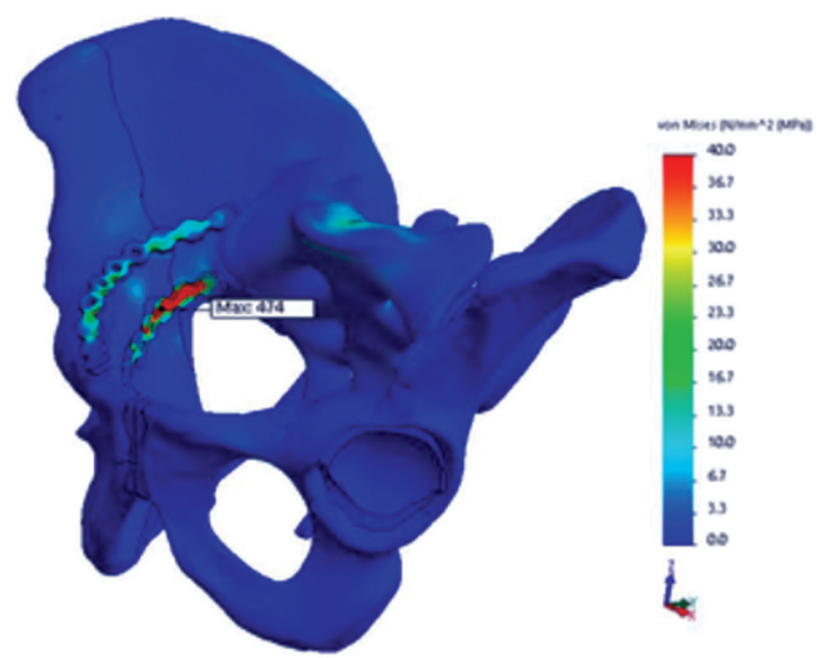

Figure 1. Distribution of tension in model in Case 1.
Case 3- Bicolumnar acetabular fracture, weight bearing on both lower extremities: load on the promontorium, in the Z-axis, $500 \mathrm{~N}$, both femurs fixed, the pelvis is posteriorly supported against displacement in the Y-axis; node-to node contact in both hip joints and at the fracture site; bonded contact in other joints; neighboring the acetabulumcranial and medial plate fixations through the linea terminalis; screw fixation of the iliac wing fracture.

Case 4- Bicolumnar acetabular fracture, weight bearing on both lower extremities: load on the promontorium, in the Z-axis, $500 \mathrm{~N}$, both femurs fixed, the pelvis is posteriorly supported against displacement in the Y-axis; node-to node contact in both hip joints and at the fracture site; bonded contact in other joints; neighboring the acetabulum-cranial plate and quadrilateral surface plate fixation through the linea terminalis; screw fixation of the iliac wing fracture.

Case 5- Bicolumnar acetabular fracture, weight bearing on both lower extremities: load on the promontorium, in the Z-axis, $500 \mathrm{~N}$, both femurs fixed, the pelvis is posteriorly supported against displacement in the Y-axis; node-to node contact in both hip joints and at the fracture site; bonded contact in other joints; neighboring the acetabulumcranial and medial plate fixations through the linea terminalis; plate fixation of the iliac wing fracture.

Case 6- Bicolumnar acetabular fracture, weight bearing on both lower extremities: load on the promontorium, in the Z-axis, $500 \mathrm{~N}$, both femurs fixed, the pelvis is posteriorly supported against displacement in the Y-axis; node-to node contact in both hip joints

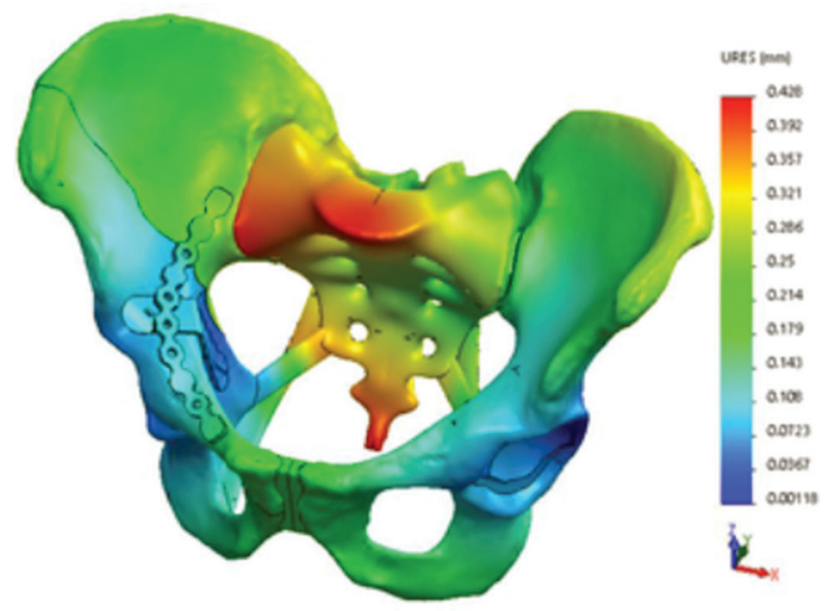

Figure 2. Movement in fracture gap in model in Case 2. 


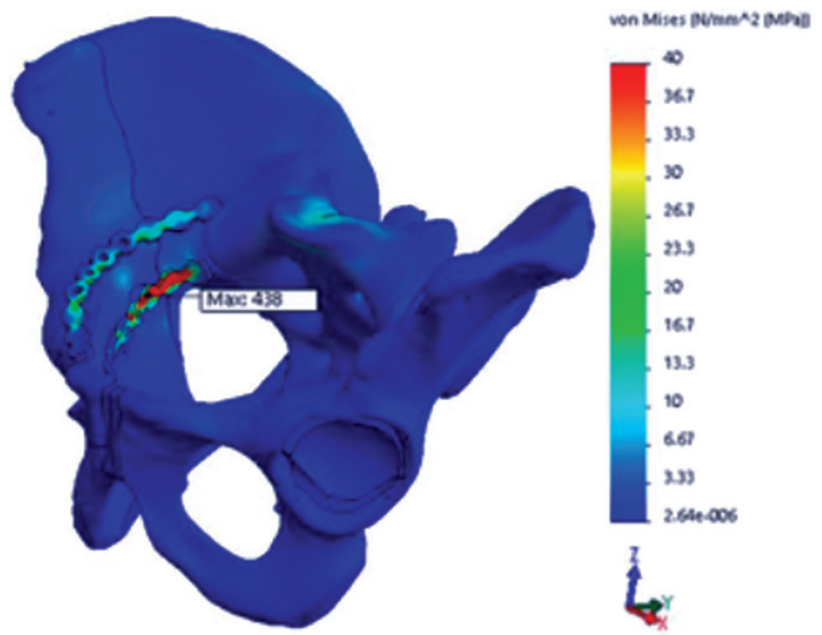

Figure 3. Distribution of tension in model in Case 3.

and at the fracture site; bonded contact in other joints; neighboring the acetabulum-cranial plate and quadrilateral surface plate fixation through the linea terminalis; plate fixation of the iliac wing fracture.

\section{Statistical analysis}

SolidWorks 2016 program was used for the finite element analysis. Automatic mesh generation was used for the finite element mesh, except in the sacrum, where 29 Jacob point Tetra elements were used for greater accuracy.

\section{RESULTS}

Case 1- Bicolumnar acetabular fracture, cranial and medial plate fixations through the linea terminalis; no fixation of the iliac wing fracture. Maximum tension in the bones was $197 \mathrm{MPa}$, in the metals was

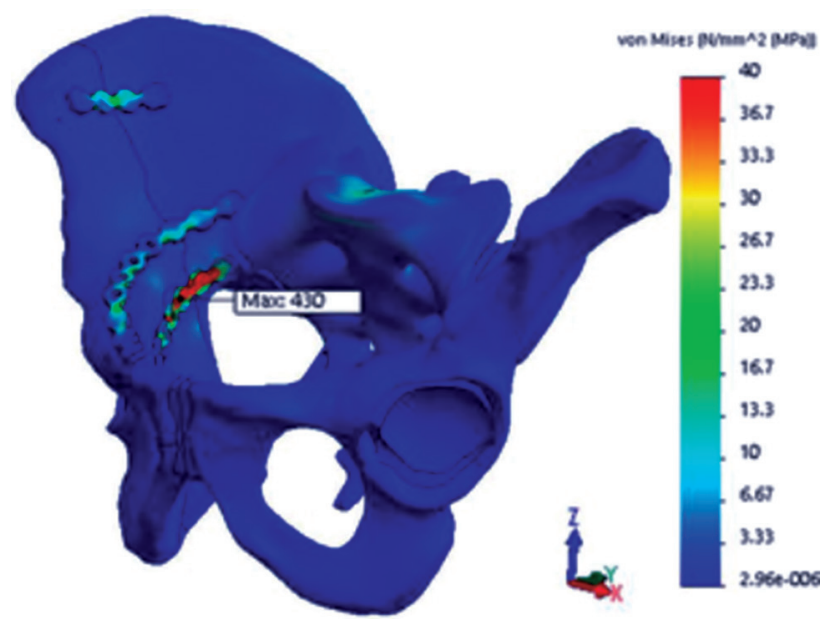

Figure 5. Distribution of tension in model in Case 5.

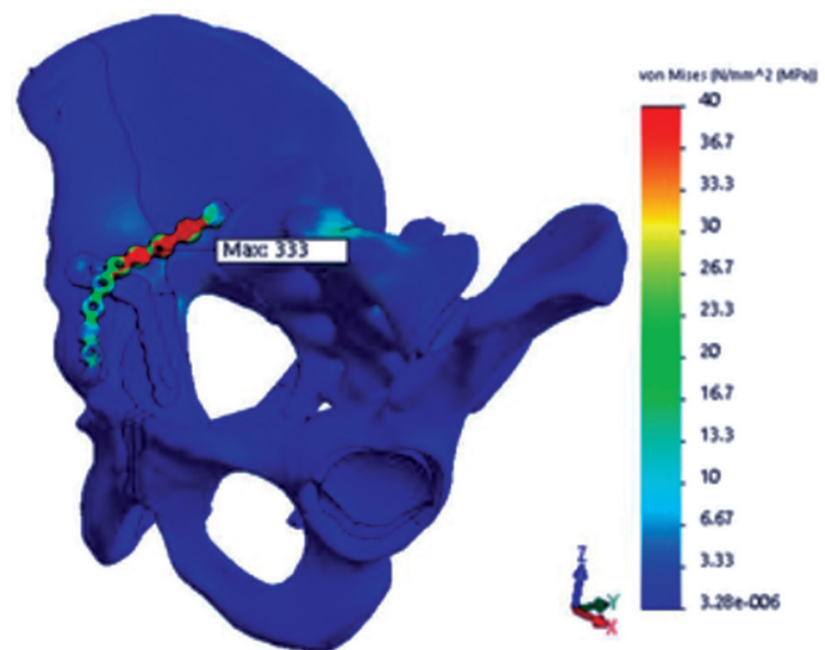

Figure 4. Distribution of tension in model in Case 4.

$474 \mathrm{MPa}$; displacement in the fracture gap of the linea terminalis was $0.088 \mathrm{~mm}$, displacement in the fracture gap of the iliac wing was $0.12 \mathrm{~mm}$ (Figure 1-tension).

Case 2- Bicolumnar acetabular fracture, cranial plate and quadrilateral surface plate fixation through the linea terminalis; no fixation of the iliac wing fracture. Maximum tension in the bones was $128 \mathrm{MPa}$, in the metals was $317 \mathrm{MPa}$; displacement in the fracture gap of the linea terminalis was $0.01 \mathrm{~mm}$, displacement in the fracture gap of the iliac wing was $0.14 \mathrm{~mm}$ (Figure 2-movement).

Case 3- Bicolumnar acetabular fracture, cranial and medial plate fixations through the linea terminalis; screw fixation of the iliac wing fracture. Maximum tension in the bones was $190 \mathrm{MPa}$, in the metals was $438 \mathrm{MPa}$; displacement in the fracture gap

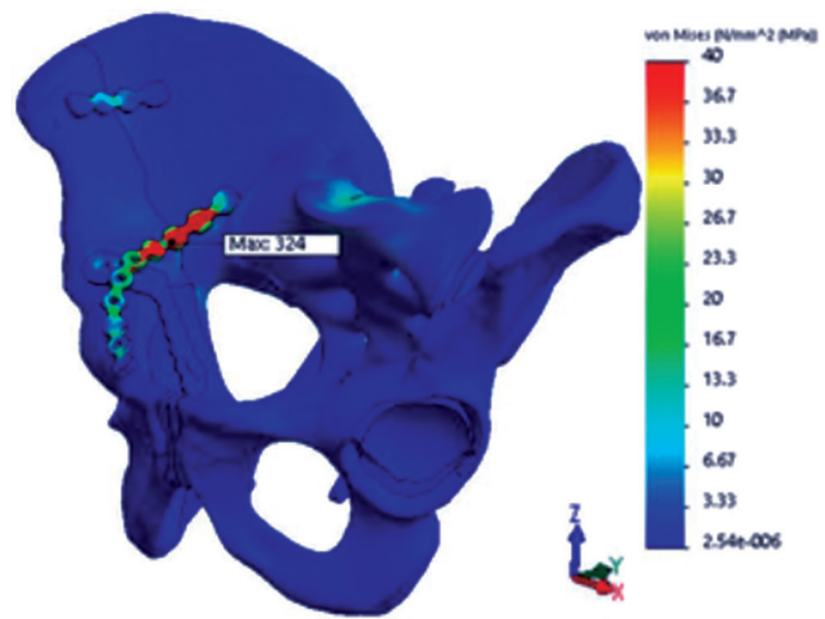

Figure 6. Distribution of tension in model in Case 6. 
TABLE II

\begin{tabular}{lcccc}
\multicolumn{4}{c}{ Maximum tension and displacement values in six models } \\
\hline & $\begin{array}{c}\text { Displacement; } \\
\text { linea terminalis (mm) }\end{array}$ & $\begin{array}{c}\text { Displacement; } \\
\text { iliac wing (mm) }\end{array}$ & $\begin{array}{c}\text { Stress; } \\
\text { bone (MPa) }\end{array}$ & $\begin{array}{c}\text { Stress; } \\
\text { implant (MPa) }\end{array}$ \\
\hline Case 1 & 0.09 & 0.12 & 197 & 474 \\
Case 2 & 0.01 & 0.14 & 128 & 317 \\
Case 3 & 0.09 & 0.11 & 190 & 438 \\
Case 4 & 0.01 & 0.12 & 140 & 333 \\
Case 5 & 0.09 & 0.04 & 187 & 430 \\
Case 6 & 0.01 & 0.05 & 116 & 324 \\
\hline
\end{tabular}

of the linea terminalis was $0.087 \mathrm{~mm}$, displacement in the fracture gap of the iliac wing was $0.11 \mathrm{~mm}$ (Figure 3-tension).

Case 4- Bicolumnar acetabular fracture, cranial plate and quadrilateral surface plate fixation through the linea terminalis; screw fixation of the iliac wing fracture. Maximum tension in the bones was $140 \mathrm{MPa}$, in the metals was $333 \mathrm{MPa}$; displacement in the fracture gap of the linea terminalis was $0.01 \mathrm{~mm}$, displacement in the fracture gap of the iliac wing was $0.12 \mathrm{~mm}$ (Figure 4-tension).

Case 5- Bicolumnar acetabular fracture, cranial and medial plate fixations through the linea terminalis; plate fixation of the iliac wing fracture. Maximum tension in the bones was $187 \mathrm{MPa}$, in the metals was $430 \mathrm{MPa}$; displacement in the fracture gap of the linea terminalis was $0.087 \mathrm{~mm}$, displacement in the fracture gap of the iliac wing was $0.04 \mathrm{~mm}$ (Figure 5-tension).

Case 6- Bicolumnar acetabular fracture, cranial plate and quadrilateral surface plate fixation through the linea terminalis; plate fixation of the iliac wing fracture. Maximum tension in the bones was $116 \mathrm{MPa}$, in the metals was $324 \mathrm{MPa}$; displacement in the fracture gap of the linea terminalis was $0.005 \mathrm{~mm}$, displacement in the fracture gap of the iliac wing was $0.05 \mathrm{~mm}$ (Figure 6-tension). The results can be seen in Table II.

\section{DISCUSSION}

Indications for the surgical treatment of acetabulum fractures include articular surface incongruence greater than $1 \mathrm{~mm}$, fracture gap displacement greater than $2 \mathrm{~mm}$, or if the "roof arc angle" is less than 45 degrees on at least one of the AP-ala-obturator views on the radiographs. Generally, an anterior approach is used for all acetabular fractures, except in posterior wall, posterior column or certain transverse fractures.
The disadvantages of the Judet-Letournel approach $^{[8]}$ are well-known: it is a rather invasive technique, where the abdominal muscles are detached from the iliac crest and the destruction of the inguinal canal. In addition, the reduction and positioning of the plate can only be performed from a cranial direction. The modified Stoppa approach is less invasive, the quadrilateral surface can be visualized, and reduction can be performed through this exposure. However, positioning of the plate and screws applied on the cranial side is more difficult. The pararectus approach-following mobilization of the external iliac artery and vein-combines the advantages of both the Judet-Letournel and Stoppa approaches. ${ }^{[9]}$ Using this approach, a plate can be positioned either cranially or medially, and in cases of bicolumnar acetabulum fractures, a quadrilateral surface plate can also be used instead of a medial plate.

The question arises which fixation allows for greater stability: the combined use of cranial and medial plate or cranial and quadrilateral surface plate? Additionally, should we perform fixation of the iliac wing if the bicolumnar acetabular fracture line reaches it and if so, should we choose plate or screw fixation?

We tried to answer these questions in our study using pelvis finite element model experiments. ${ }^{[10]}$ In our current study, we used the same plastic pelvis model, which we had used in our previous research. Computed tomography images were used to model the different thicknesses of the cortical layers of the bone, but we neglected the role of the cancellous layer, as other authors have also done. ${ }^{[1]}$ We modelled the symphysis and sacroiliac joints to be less stiff. We modelled a bicolumnar fracture of the acetabulum. Either cranial and medial plate fixation through the linea terminalis or cranial plate and quadrilateral surface plate was used for osteosynthesis of the fracture. The fracture running 
through the iliac wing was not fixed in the first two cases and was fixed with screw or plate fixation in the further cases. The bonded connection between the plate and screws corresponds to the plate-screw contact in locked plate fixation. As in our previous studies, we modelled smooth, frictionless fracture surfaces. The measurements were performed with the model standing upright on both lower limbs.

In conclusion, the cranial and quadrilateral surface plate combination offered a relatively more stable fixation than cranial and medial plate combination, with or without the fixation of the iliac wing fracture; however, the differences in the displacement values were not significant. The fixation of the iliac wing fracture did not significantly improve the stability of the osteosynthesis through the linea terminalis. Less displacement was observed in the iliac wing fracture when plate fixation was used compared to screw fixation. Based on the tension values measured in the bones and metals, the stability of the fixation was adequate, and implant failure or loosening is not anticipated. Based on the results, in bicolumnar acetabular fractures, if the reduction does not require an anterior approach, it is not necessary to fix the iliac wing fracture only to improve the stability of the fixation. If the reduction does require an anterior approach, it is worth fixing the iliac wing fracture with the technically less demanding screw fixation.

\section{Declaration of conflicting interests}

The authors declared no conflicts of interest with respect to the authorship and/or publication of this article.

\section{Funding}

The authors received no financial support for the research and/or authorship of this article.

\section{REFERENCES}

1. AO Surgery reference. Available from: www.aosurgery.org

2. Hirvensalo E, Lindahl J, Kiljunen V. Modified and new approaches for pelvic and acetabular surgery. Injury 2007;38:431-41.

3. Keel MJ, Ecker TM, Cullmann JL, Bergmann M, Bonel HM, Büchler L, et al. The Pararectus approach for anterior intrapelvic management of acetabular fractures: an anatomical study and clinical evaluation. J Bone Joint Surg [Br] 2012;94:405-11.

4. Atik OŞ. Are all case reports worth publishing? Eklem Hastalik Cerrahisi 2016;27:61.

5. Abé H, Hayashi K, Sato M. Data Book on Mechanical Properties of Living Cells, Tissues, and Organs. Tokyo: Springer Verlag;, 1996.

6. Sztrinkai G, Bodzay T, Pajor S, Erdös P, Vendégh Z, Jónás $Z$, et al. Further development of our finite element pelvic model to compare fixation methods for pelvic fractures. Eklem Hastalik Cerrahisi 2014;25:8-14.

7. Bodzay T, Szita J, Manó S, Kiss L, Jónás Z, Frenyó S, et al. Biomechanical comparison of two stabilization techniques for unstable sacral fractures. J Orthop Sci 2012;17:574-9.

8. Letournel E. The treatment of acetabular fractures through the ilioinguinal approach. Clin Orthop Relat Res 1993;292:62-76.

9. Sztrinkai G, Bodzay T, Madarász B, Zoltán G, Gál T, Váradi $\mathrm{K}$. Intrapelvic acetabulum surgery: does the positioning of the plate fixation play a role in the stability of the osteosynthesis? Eklem Hastalik Cerrahisi 2015;26:126-30.

10. Bodzay T, Flóris I, Váradi K. Comparison of stability in the operative treatment of pelvic injuries in a finite element model. Arch Orthop Trauma Sur. 2011;131:1427-33.

11. Anderson A, Peters C, Ellis B, Tuttle B, Balling S, Weiss J. Subject specific finite element modeling of hip joint biomechanics Available from: http://www.sci.utah.edu/ balling/FEdoc/ SubjectSpecificFiniteElementModelingOfHipJoint 